\title{
INCOME SMOOTHING DAN FAKTOR-FAKTOR YANG MEMPENGARUHINYA PADA PERUSAHAAN PARIWISATA YANG TERDAFTAR DI BURSA EFEK INDONESIA
}

\author{
M. Dwi Syahputra ${ }^{1 *}$, Ngatemin ${ }^{2}$ \\ ${ }^{1}$ Sekolah Tinggi Ilmu Ekonomi Harapan \\ Jl. Imam Bonjol No.35, J A T I, Kec. Medan Maimun, Kota Medan, Sumatera Utara \\ 2 Politeknik Pariwisata Medan \\ Jl. Rumah Sakit H. No.12, Kenangan Baru,. Percut Sei Tuan, Deli Serdang, Sumatera Utara \\ 1m.dwisyahputra77@gmail.com,2ngatemin@poltekparmedan.ac.id \\ ${ }^{*}$ Correcpondig author
}

Received: Agustus, 2020

Accepted: September, 2020

Published: September, 2020

\begin{abstract}
This research was conducted with the aim to determine the effect of profitability, liquidity, financial leverage and ownership structure on income smoothing in Tourism Companies Listed on the Indonesia Stock Exchange. The approach used in this research is an associative approach. Data collection techniques in this study using documentation techniques. The total population of 23 companies there are 11 companies with 6 years of observation so the number of samples is 66 samples. Data analysis using multiple linear regression analysis of data processing in this study using the SPSS (Statistic Package for the Social Sciens) software program version 22.00. The results showed that partially Profitability had a positive and significant effect on Income Smoothing, Liquidity, Financial Leverage and Ownership Structure had no negative effect and no significant effect on income smoothing. Simultaneously Profitability, Liquidity, Financial Leverage and Ownership Structure jointly influence and significantly affect Income Smoothing in Tourism Companies listed on the Indonesia Stock Exchange for the period 2012-2017.
\end{abstract}

Keywords: profitability, liquidity, financial leverag, ownership structure, income smoothing

\begin{abstract}
Abstrak
Penelitian ini dilakukan dengan tujuan untuk mengetahui pengaruh Profitabilitas, likuiditas, financial leverage dan struktur kepemilikan terhadap income smoothing pada Perusahaan Pariwisata yang Terdaftar di Bursa Efek Indonesia. Pendekatan yang digunakan dalam penelitian ini adalah pendekatan asosiatif. Teknik pengumpulan data dalam penelitian ini menggunakan teknik dokumentasi. Jumlah populasi sebanyak 23 perusahaan tetapi hanya terdapat 11 perusahaan dengan 6 tahun Pengamatan sehingga jumlah sample 66 sampel. Analisis data menggunakan Analisis regresi linier berganda. Pengolahan data dalam penelitian ini menggunakan program software SPSS (Statistic Package for the Social Sciens) versi 22.00 Hasil penelitian menunjukkan bahwa secara parsial Profitabilitas berpengaruh positif dan signifikan terhadap income smoothing, sedangkan likuiditas, financial leverage dan struktur kepemilikan berpengaruh negatif dan tidak signifikan terhadap income smoothing. Secara simultan Profitabilitas, likuiditas, financial leverage dan struktur
\end{abstract}


Syahputra, Ngantemin

kepemilikan berpengaruh dan signifikan terhadap income smoothing pada Perususahaan Pariwisata yang terdaftar di Bursa Efek Indonesia periode 2012-2017.

Kata Kunci: profitabilitas, likuiditas, financial leverage, struktur kepemilikan, income smoothing

\section{PENDAHULUAN}

Perusahaan Pariwisata merupakan salah satu faktor penting dalam perkembangan perekonomian di Indonesia. Pariwisata adalahgabungan dari berbagai kegiatan, layanan, dan industri yang memberikan pengalaman perjalanan : transportasi, akomodasi, tempat makan dan minum, toko, hiburan, aktivitas, dan layanan perhotelan lainnya yang tersedia untuk perorangan atau kelompok yang jauh dari rumah (Muljadi 2009 : 8).

Laporan keuangan juga suatu alat yang sangat penting untuk memperoleh informasi sehubungan dengan posisi keuangan dan hasil-hasil yang telah dicapai oleh perusahaan yang bersangkutan (Fahmi, 2013 : 2). Salah satu tindakan tersebut adalah dengan cara manajemen laba. Salah satu upaya yag dilakukan untuk menjaga kestabilan informasi keuangan yang menggambarkan kinerja keuangan perusahaan adalah dengan melakukan manajemen laba dengan melakukan perataan laba (income smoothing) yaitu perataan fluktuasi laba yang dilaporkan yang dianggap normal bagi perusahaan (Aji dan Mita , 2010). Beberapa penelitian terdahulu menyatakan bahwa Income Smoothing dapat dipengaruhi oleh beberapa faktor seperti profitabilitas likuiditas, financial leverage dan struktur kepemilikan (Budiasih, 2009:47), Muslichah (2015), Mufarrokhah Trisnawati, dkk (2017), (Prasetya (2013), (Harris \& Shiddiq ,2013), (Jensen dan Meckling, 1976), Danang Surya Dahana (2016). Jenny Altany Lestari Lay (2017), Siti Herlina (2017).

\section{TINJAUAN PUSTAKA 2.1 Income Smoothing}

Menurut Beildman perataan laba adalah suatu usaha yang dilakukan manajemen untuk menekan variasi dalam laba sejauh yang dimungkinkan oleh prinsip akuntansi (Chariri, 2007:370). Perataan laba menunjukkan suatu usaha manajemen perusahaan untuk mengurangi variasi abnormal laba alam batas-batas yang diijinkan dalam praktik akuntansi dan prinsip manajemen yang wajar. Disisi lain perataan laba menurut Chariri (2007 : 370) adalah suatu usaha yang dilakukan manajemen untuk menekan variasi dalam laba sejauh yang dimungkinkan oleh prinsip akuntansi. Budiasih (2007:4) menyatakan perataan laba adalah tindakan yang dilakukan dengan sengaja untuk mengurangi variabilitas laba yang dilaporkan agar dapat mengurangi risiko pasar atas saham dan dapat meningkatkan harga saham perusahaan.

\subsection{Profitabilitas}

Profitabilitas merupakan ukuran penting untuk menilai sehat atau tidaknya perusahaan yang mempengaruhi investor untuk membuat keputusan. (Suwito dan Herawaty, 2005:139). Profitabilitas perusahaan dalam penelitian ini yang diproksikan dengan Return on Equity (ROE). Hanafi (2009) menyebutkan bahwa Return on Equity (ROE) digunakan untuk mengukur kemampuan perusahaan menghasilkan laba berdasarkan modal saham tertentu yang merupakan ukuran profitabilitas dari sudut pandang pemegang saham diduga mempengaruhi tindakan perataan laba.

\subsection{Likuiditas}

Likuiditas perusahaan merupakan kemampuan perusahaan untuk 
menyelesaikan kewajiban jangka pendeknya atau menganalisa dan menginterpretasikan posisi keuangan jangka pendek perusahaan (Munawir, 2002). Menurut Brigham dan Houston (2009), rasio likuiditas merupakan rasio yang digunakan untuk menunjukkan hubungan kas dan aktiva lancar lain dengan kewajiban lancar yang dimiliki perusahaan. Sedangkan menurut Marcus (2007), likuiditas merupakan kemampuan perusahaan untuk menjual aset guna mendapatkan kas pada waktu singkat. Rasio ini menunjukkan sejauh mana aset lancar dengan utang lancar menutupi kewajiban-kewajiban lancar. Semakin besar perbandingan aset lancar dengan utang lancar semakin tinggi kemampuan perusahaan menutupi kewajiban jangka pendeknya.

\subsection{Financial Leverage}

Menurut Kasmir (2014:153) terdapat beberapa tujuan perusahaan menggunakan rasio leverage, yaitu : 1) untuk mengetahui posisi perusahan terhadap kewajiban kepada pihak lainnya; 2) untuk menilai kemampuan perusahaan dalam memenuhi kewajiban yang bersifat tetap; 3) untuk menilai keseimbangan antara nilai aset khususnya aset tetap dengan modal; 4) untuk menilai seberapa besar aset perusahaan yang dibiayai oleh utang; 5) untuk menilai seberapa besar pengaruh utang perusahaan terhadap pengelolaan aset. Leverage adalah perbandingan antara total kewajiban dengan total asset perusahaan. Leverage terjadi akibat perusahaan menggunakan sumber dana atas pinjaman perusahaan setiap tahunnya yang dibebani biaya bunga". Tingkat Leverage yang tinggi mengindifikasikan resiko perusahaan yang tinggi pula sehingga kreditor (stakeholder) sering memperhatikan besarnya resiko ini dengan pemikiran jika perusahaan memiliki utang yang tinggi maka perusahaan akan dihadapkan pada kewajiban yang tinggi pula dan pada kondisi perusahaan rugi atau pada posisi laba yang tidak terlalu tinggi maka kreditor akan dihadapkan pada resiko ketidakmampuan perusahaan dalam membayar utangnya. Perusahaan umumnya menggunakan pendanaan ekuitas maupun hutang (leverage) untuk membiayai operasionalnya, semakin tinggi leverage perusahaan, maka semakin tinggi pula risiko yang dimiliki perusahaan tersebut.

\subsection{Struktur Kepemilikan}

Struktur kepemilikan adalah jumlah atau proporsi kepemilikan saham perusahaan. Struktur kepemilikan saham terdiri dari kepemilikan institusional, kepemilikan manajerial, kepemilikan Publik, dan kepemilikan keluarga. Struktur kepemilikan dapat dijelaskan dari dua sudut pandang, yaitu pendekatan keagenan dan pendekatan informasi asimetri.

Menurut pendekatan keagenan, struktur kepemilikan merupakan suatu mekanisme untuk mengurangi konflik kepentingan antara manajer dengan pemegang saham. Pendekatanketidakseimbangan

informasi memandang mekanisme struktur kepemilikan sebagai suatu cara untuk mengurangi ketidakseimbangan informasi antara insiders dan outsiders melalui pengungkapan informasi di dalam pasar modal. Adanya kepemilikan saham oleh pihak manajemen akan menimbulkan suatu pengawasan terhadap kebijakan-kebijakan yang diambil oleh manajemen perusahaan. Kepemilikan manajerial juga dapat diartikan sebagai persentase saham yang dimiliki oleh manajer dan direktur perusahaan pada akhir tahun untuk masing-masing periode pengamatan.

\section{HASIL DAN PEMBAHASAN}

\subsection{Pengaruh Profitabilitas, Likuiditas, Financial Leverage, Struktur Kepemilikan terhadap Income Smoothing.}

Uji statistik F menunjukkan apakah semua variabel independen atau bebas yang dimasukkan dalam model 
mempunyai pengaruh secara bersamasama terhadap variabel independen. Pengujian ini dilakukan dengan menggunakan tingkat signifikansi 5\%. Jika nilai signifikansi $f<0,05$ artinya terdapat pengaruh yang signifikan antara semua variabel independen terhadap variabel dependen. Jika nilai signifikansi f > 0,05 artinya tidak terdapat pengaruh antara variabel independen terhadap variabel dependen (Ghozali, 2011). Nilai untuk variabel independent adalah 3.202 dan dengan $\alpha=5 \%$ diketahui sebesar 2.52. dengan demikian lebih besar dari dan nilai signifikan variabel independent sebesar $0.019>0.05$ artinya dari hasil tersebut dapat disimpulkan bahwa $\mathrm{Ha}$ diterima (Ho ditolak) menunjukkan bahwa ada pengaruh yang signifikan antara variabel Independent terhadap variabel Dependent pada perusahaan Pariwisata yang terdaftar di Bursa Efek Indonesia.

\subsection{Pengaruh profitabilitas, likuiditas, financial leverage, struktur kepemilikan terhadap income smoothing secara parsial.}

Pengaruh profitabilitas, likuiditas, financial leverage, struktur kepemilikan terhadap income smoothing secara parsial dapat dilihat dari Uji T. Uji t digunakan dalam penelitian ini digunakan untuk mengetahui kemampuan dari masing-masing variabel independen. Alasan lain uji $t$ dilakukan untuk menguji apakah variabel bebas $(\mathrm{X})$ secara parsial atau individual mempunyai hubungan signifikan atau tidak terhadap variabel terikat (Y). Hasil pengujian statistic $t$ pada tabel diatas dapat dijelaskan sebagai berikut :

\subsection{Pengaruh Profitabilitas terhadap Income Smoothing}

Uji $t$ digunakan untuk mengetahui apakah Profitabilitas berpengaruh secara individual (parsial) mempunyai hubungan yang signifikan atau tidak terhadap Income Smoothing. Nilai untuk variabel Profitabilitas adalah
2.378 dan dengan $\alpha=5 \%$ diketahui sebesar 1.998. dengan demikian lebih besar dari dan nilai signifikan Profitabilitas sebesar $0.021<0.05$ artinya dari hasil tersebut didapat kesimpulan bahwa $\mathrm{HO}$ ditolak (Ha diterima) menunjukkan bahwa ada pengaruh positif dan signifikan antara Profitabilitas terhadap Income Smoothing pada perusahaan pariwisata yang terdaftar di Bursa Efek Indonesia. Artinya profitabilitas berpengaruh terhadap indeks Perataan laba atau income smoothing perusahaan pariwisata yang terdaftar di Bursa Efek Indonesia. Dimana profitabilitas dipandang sebagai target yang harus dicapai yang dapat menghasilkan informasi bagi investor dalam pengambilan keputusan. Hal ini berkaitan dengan teori signaling karena sinyal-sinyal berupa profitabilitas yang besar mengakibatkan besarnya perhatian dari para pemangku kepentingan sehingga mendorong manajer untuk melakukan perataan laba. Profitabilitas yang sering berubah-ubah menandakan bahwa perusahaan tersebut memiliki risiko dalam memberikan deviden kepada investor, sehingga untuk meningkatkan kepercayaan pasar manajer akan berupaya mempertahankan profitabilitas agar tetap konsisten dan stabil. Disamping itu kontrak skim bonus oleh pemilik dan manajer menjadi pertimbangan lain bagi manajer dalam mempertahankan tingkat laba yang dihasilkan. Income smoothing merupakan suatu upaya nyata untuk mengurangi naik-turunnya laporan laba tersebut sehingga tidak merusak hubungan harapan laba perusahaan dengan portofolio pasar maupun kompensasi bonus yang akan di terima.

Hasil penelitian ini sesuai dengan hasil penelitian yang dilakukan oleh Danang (2016) yang menyimpulkan bahwa profitabilitas berpengaruh terhadap income smoothing. Menurut peneliti terdahulu yang di lakukan oleh Muffarokhah dkk (2017) menyimpulkan bahwa profitabilitas berpengaruh 
terhadap income smoothing. Sedangkan Hasil penelitian ini bertentanga dengan hasil penelitian yang dilakukan oleh Jenny (2017) menyimpulkan bahwa variabel profitabilitas berpengaruh negatif terhadap income smoothing.

\subsection{Pengaruh Likuiditas terhadap Income Smoothing}

Nilai untuk variabel likuiditas adalah 0.208 dan dengan $\alpha=5 \%$ diketahui sebesar 1.998. dengan demikian lebih kecil dari dan nilai signifikan likuiditas sebesar $0.836>0.05$ artinya dari hasil tersebut didapat kesimpulan bahwa $\mathrm{H} 0$ diterima (Ha ditolak) menunjukkan bahwa tidak ada pengaruh dan tidak signifikan antara likuiditas terhadap Income Smoothing pada perusahaan pariwisata yang terdaftar di Bursa Efek Indonesia. Artinya likuiditas tidak tidak berpengaruh terhadap income smoothing perusahaan pariwisata yang terdaftar di Bursa Efek Indonesia. Dimana para pemegang saham atau investor yang cenderung memperhatikan laporan laba saja yang membuat manajer tidak perlu mengkhawatirkan apabila nilai likuiditas terlalu tinggi atau rendah. Asalkan laba stabil, tinggi rendahnya likuiditas tidak mempengaruhi penilaian pemegang saham terhadap manajemen perusahaan. Dengan demikianbesar kecilnya likuiditas belum dapat mempengaruhi besar kecilnya income smoothing. Hasil penelitian ini sesuai dengan hasil penelitian yang dilakukan oleh Danang (2016) menyimpulkan bahwa likuiditas berpengaruh tidak signifikan terhadap income smoothing.

\subsection{Pengaruh Financial Leverage terhadap Income Smoothing}

Uji t digunakan untuk mengetahui apakah Financial Leverage berpengaruh secara individual (parsial) mempunyai hubungan yang signifikan atau tidak terhadap income smoothing. Nilai untuk variabel Financial Leverage adalah 1.764 dan dengan $\alpha=5 \%$ diketahui sebesar 1.998. dengan demikian lebih kecil dari dan nilai signifikan Financial Leverage sebesar $0.083>0.05$ artinya dari hasil tersebut didapat kesimpulan bahwa $\mathrm{HO}$ ditolak (Ha diterima) menunjukkan bahwa ada pengaruh negatif dan signifikan antara Financial Leverage terhadap income smoothing pada perusahaan Pariwisata yang terdaftar di Bursa Efek Indonesia.

Artinya financial leverage tidak berpengaruh terhdap income smoothing perusahaan pariwisata yang terdaftar di Bursa Efek Indonesia. Dimana semakin besar hutang suatu perusahaan maka semakin tinggi pula resiko yang harus ditanggung oleh para investor. Artinya bahwa semakin tinggi tingkat Leverage keuangan perusahaan, maka resiko yang akan ditanggung oleh para pemilik modal atau kreditor juga akan semakin meningkat. Perusahaan umumnya menggunakan pendanaan ekuitas maupun hutang (leverage) untuk membiayai operasionalnya, semakin tinggi leverage perusahaan, maka semakin tinggi pula risiko yang dimiliki perusahaan tersebut. Kreditor tidak akan memberikan dana tanpa adanya jaminan pengembalian dan jaminan keamanan atas dana tersebut. Oleh karena itu, agar performan perusahaan terlihat baik di mata kreditor, perusahaan yang mengalami kendala debt to equity akan memilih menggunakan alternatif akuntansi yang akan meningkatkan pendapatan, atau dengan kata lain perusahaan yang mendekati default dengan perjanjian hutang sangat potensial melakukan income smoothing.

Hasil penelitian ini sesuai dengan hasil penelitian yang dilakukan oleh Mufarrokhah dkk (2017) menyimpulkan bahwa variabel financial leverage tidak berpengaruh terhadap income smoothing. Menurut penelitian terdahulu yang dilakukan oleh Dewi (2015) menyimpulkan bahwa bahwa financial leverage tidak berpengaruh terhadap income smoothing. Sedangkan Hasil penelitian ini bertentangan dengan hasil penelitian yang dilakukan oleh Jenny (2017) dimana hasil Penelitian 
menunjukkan bahwa Hasil penelitian menunjukkan bahwa variabel leverage berpengaruh positif terhadap income smoothing karena leverage (DER) memiliki tingkat signifikansi lebih kecil dari alpha.

\subsection{Pengaruh Struktur Kepemilikan terhadap Income Smoothing}

Nilai untuk variabel struktur kepemilikan adalah -0.052 dan dengan $\alpha=5 \%$ diketahui sebesar 1.998 dengan demikian lebih besar dari dan nilai signifikan struktur kepemilikan sebesar $0.959>0.05$ artinya dari hasil tersebut didapat kesimpulan bahwa HO diterima (Ha ditolak) menunjukkan bahwa tidak ada pengaruh negatif dan tidak signifikan antara struktur kepemilikan terhadap Income Smoothing pada perusahaan pertambangan yang terdaftar di Bursa Efek Indonesia. Artinya Struktur Kepemilikan tidak tidak berpengaru terhadap perusahaan pariwisata yang terdaftar di Bursa Efek Indonesia. Dimana struktur kepemilikan Struktur kepemilikan adalah proporsi kepemilikan publik dan manajemen dalam kepemilikan suatu perusahaan. Struktur kepemilikan merupakan bentuk komitmen dari para pemegang saham untuk mendelegasikan pengendalian dengan tingkat tertentu kepada para manajer. Kepemilikan manajerial menjadi proksi struktur kepemilikan yaitu merupakan kepemilikan saham oleh kelompok elit perusahaan yang terdiri dari saham yang dimiliki oleh komisaris dan direksi. Melalui regresi logistik telah diketahui bahwa struktur kepemilikan manajerial tidak berpengaruh terhadap praktik perataan laba. Maka dapat disimpulkan bahwa struktur kepemilikan manajerial tidak memiliki pengaruh signifikan terhadap praktik perataan laba.

Hasil penelitian ini sesuai dengan hasil penelitian yang dilakukan oleh Lusy (2014) menyimpulkan hasil penelitiannya yaitau bahwa struktur kepemilikan tidak berpengaruh signifikan terhadap Income Smoothing.
Berdasarkan hasil penelitian terdahulu yang dilakukan oleh Erni dkk (2016) menyimpulkan bahwa berdasarkan hasil uji regresi logistik (logistic regression) menunjukkan bahwa kepemilikan manajerial tidak berpengaruh terhadap income smoothing. Sedangkan Hasil penelitian ini bertentangan dengan hasil penelitian yang dilakukan menurut Siti Herlina (2017) menyimpulkan bahwa Kepemilikan manajerial berpengaruh terhadap income smoothing, hal ini mengindikasikan bahwa dengan adanya kepemilikan manajerial disuatu perusaahaan maka akan mempermudah manajer untuk melakukan perataan laba hal ini dikarenakan manajemen sebagai pemegang saham ingin perusahaan terlihat memiliki kinerja yang baik sehingga dapat menyakinkan investor untuk berinvestasi.

\section{KESIMPULAN}

Berdasarkan data yang diperoleh maupunn analisis data yang telah dilakukan serta pembahasan yang telah dilakukan pada bab sebelumnya, maka dapat ditarik beberapa kesimpulan. Secara simultan profitabilitas, likuiditas, financial leverage dan struktur kepemilikan berpengaruh positif dan signifikan terhadap income smoothing pada perusahaan pariwisata yang terdaftar di Bursa Efek Indonesia periode 2012-2017. Hal ini sejalan dengan hasil penelitian terdahulu yang dilakukan oleh Muslichah (2015) yang menyimpulkan hasil penelitian menunjukkan profitabilitas, size perusahaan, dan financial leverage berpengaruh terhadap terhadap income smoothing.

Secara parsial profitabilitas berpengaruh positif dan signifikan terhadap Income Smoothing pada perusahaan pariwisata yang terdaftar di Bursa Efek Indonesia periode 20122017. Hal ini sesuai dengan hasil penelitian yang dilakukan oleh Danang (2016) yang menyimpulkan bahwa profitabilitas berpengaruh terhadap income smoothing. Secara parsial likuiditas, financial leverage, dan 
struktur kepemilikan tidak berpengaruh dan tidak signifikan terhadap income smoothing pada perusahaan pariwisata yang terdaftar di Bursa Efek Indonesia periode 2012-2017. Hal ini sesuai dengan hasil penelitian yang dilakukan oleh Mufarrokhah dkk (2017) menyimpulkan bahwa variabel financial leverage tidak berpengaruh terhadap income smoothing. Sedangkan Hasil Penelitian yang dilakukan oleh Lusy (2014) menyimpulkan bahwa struktur kepemilikan tidak berpengaruh signifikan terhadap Income Smoothing.

\section{DAFTAR PUSTAKA}

Aji, Y. D. \& Aria, M. F. (2010). Pengaruh Profitabilitas, Risiko Keuangan, Nilai Perusahaan, dan Struktur Kepemilikan Terhadap Praktek Perataan Laba : Studi Empiris Perusahaan Manufaktur yang Terdapat di BEI". Simposium Nasional Akuntansi XIII, Universitas Jendral Soedirman Purwokerto.

Azhari, F. (2009). Analysis of Factors Influencing Income Smoothing on Manufacturing Companies of Basic an Chemical Industry Sector Listed in Indonesia Stock Exchange.

Belkaoui, A.R. (2007). Accounting Theory. 5th Edition. Buku 2. Edisi Terjemahan. Jakarta: Salemba Empat.

Brigham \& Houston. (2009). Dasar-Dasar Manajemen Keuangan. Jakarta: Salemba Empat.

Budiasih, I. G. A .N. (2009). Faktor-Faktor yang Mempengaruhi Praktik Perataan Laba. Media AUDIT. Jurnal Akuntansi dan Bisnis, Vol. 4. Januari, hal:114.

Bodie, Z., A. K, \& Marcus, A. J. (2007). Investment, (7th Ed). New York: McGrow-Hill.

Boediono. (2008). Ekonomi Moneter Edisi 3. Yogyakarta: BPFE.

Chariri, A. \& Ghozali, I. (2007). Teori Akuntansi. Semarang: Badan Penerbit Universitas Diponegoro.

Dewi, D. O. (2010). Pengaruh Jenis Usaha, Ukuran Perusahaan dan Financial
Leverage Terhadap Tindakan Perataan Laba pada Perusahaan yang Terdaftar di BEI. Skripsi: Universitas Diponegoro.

Eckel, N. (1981). The Income Smoothing Hypothesis Revisted. Abacu. Vol. 17. No 1 hal 28-40.

Fahmi, I. (2013). Analisis Laporan Keuangan. Bandung: Alfabeta.

Imam, G., Chariri \& Anis. (2007). Teori Akuntansi. Semarang: Badan Universitas Diponegoro.

Halim, A. \& Mamduh M. H. (2009). Analisis Laporan Keuangan. Edisi 4. UPP STIM YKPN. Yogyakarta;

Herlina, S. (2017). Pengaruh Ukuran Perusahaan, Financial Leverage, Net Profit Margin Dan Struktur Kepemilikan Terhadap Tindakan Perataan Laba Padaperusahaan Manufaktur Yang Terdaftar Di Beiperiode 2011-2014. Jurnal Online Mahasiswa Fakultas Ekonomi Universitas Riau. Vol 4 No 7

Istianah, M. (2006). Pengaruh Faktor Debt to Equity Ratio, Dividen Payout Ratio, Profitabilitas, dan Size Perusahaan terhadap Tindakan Perataan Laba (Income Smoothing) pada Perusahaan-perusahaan yang terdaftar di Bursa Efek Jakarta Tahun 2000-2004. Skripsi S1. FE UNNES. Tidak Dipublikasikan.

Jensen, M.C. \& W.H. Meckling. (1976). Theory of the firm: Managerial Behavior, Agency Costs and Ownership structure. Journal of Financial Economics 3, 305-360.

Kasmir, (2014). Analisis Laporan Keuangan, Edisi Pertama, Cetakan Ketujuh. Jakarta: PT. Rajagrafindo Persada.

Kasmir. (2009). Analisis laporan keuangan. Jakarta : PT Raja Grafindo Persada.

Lay, J. (2017). Engaruh Ukuran Perusahaan, Profitabilitas Dan Leverage Terhadap Perataan Laba Pada Perusahaan Manufaktur Yang Terdaftar Di Bursa Efek Indonesia Tahun 2013-2015. Skripsi Sekolah 
Syahputra, Ngantemin

Tinggi Ilmu Ekonomi Perbanas Surabaya.

Li-Jung, T. \& Chien-Wen, L. (2007). Relationship Between Income Smoothing and Company Profitability: An Empirical Study. International Journal of Management. Taiwan, Desember 2007.

Muljadi, A. J. (2009). Kepariwisataan dan Perjalanan, Jakarta: PT RajaGrafindo Persada.

Munawir S. (2002). Analisis Laporan Keuangan. Yogyakarta: Liberty

Muslichah. 2015. Pengaruh Profitabilitas, Size \& Financial Leverage Terhadap Income Smoothing (Studi Pada Perusahaan Manufaktur Yang Terdaftar Di Bursa Efek Indonesia). Jurnal JIBEKA Volume 9 Nomor 2. h, 40-47.

Nawawi, H. (2008). Manajemen Sumber Daya Manusia untuk Bisnis yang Kompetitif. Cetakan Keempat. Penerbit Gadjah Mada University Press, Yogyakarta.

Prabayanti, N.L.P.A. \& Yasa, G. W. (2011). Perataan Laba (Income Smoothing) dan Analisis Faktor-Faktor yang Mempengaruhinya (Studi pada Perusahaan Manufaktur yang Terdaftar di Bursa Efek Indonesia". Jurnal Akuntansi dan Bisnis. Volume 1 Januari 2011.

Prasetya, H. (2013). Pengaruh Ukuran Perusahaan, Profitabilitas, Financial Leverage, Likuiditas dan Klasifikai KAP terhadap Praktik Perataan Laba. E-Jurnal Akuntansi UNDIP. Vol.2, No. 4.

Riyanto, B. (1995). Dasar-Dasar Pembelanjaan Perusahaan. Yogyakarta: BPFE Yogyakarta.

Siregar S.V.N.P. \& Utama, S, (2006) Pengaruh Struktur Kepemilikan, Ukuran Perusahaan, dan Praktek Corporate Governance Terhadap Pengelolaan Laba (Earnings Management). Simposium Nasional Akuntansi VIII, IAI, 2005.

Suwito, E. \& Herawaty, A. (2005). Analisis Pengaruh Karakteristik
Perusahaan Terhadap Tindakan Perataan Laba yang dilakukan Oleh Perusahaan yang Terdaftar di BEJ. Dalam SNA VIII Solo. September 2005.

Simbolon, H. A. (2010). Perataan Laba (Income Smoothing). Jurnal. Akuntansi Bisnis Universitas. Volume.2, Nomor. 8

Sujono \& Soebiantoro, U. (2007). Pengaruh Struktur Kepemilikan Saham, Leverage, Faktor intern dan Faktor ekstern terhadap Nilai Perusahaan. Jurnal Manajemen dan Kewirausahan. Vol. 9. No 1. Maret: 41-48.

Sugeng. (2009). Pengaruh Struktur Kepemilikan dan Struktur Modal terhadap Kebijakan Inisiasi Dividen Di Indonesia. Jurnal ekonomi Bisnis Tahun 14 Nomor 1 Maret 2009, 3748.

Sugiyono. (2012). Metode Penelitian Kuantitatif Kualitatif R\&D. Bandung: Alfabeta.

Trisnawati, dkk. (2017). Pengaruh Profitabilitas, Dividend Payout Ratio Dan Financial Leverage Terhadap Praktik Perataan Laba (Studi Pada Perusahaan Yang Terdaftar Pada Indeks Lq45 Tahun 2011-2016) The Effect Of Profitability, Dividend Payout Ratio And Financial Leverage To The Income Smoothing (Studies On Companies of Lq45 Index In The Year 2011-2016). eProceeding of Managemen. Vol.4, No.3

Weston, J. F. \& Copeland, T.E. (1997). Manajemen Keuangan. Jilid 1 dialih bahasakan oleh Jaka Wasana dan Kibrandoko, Binarupa Aksara. Jakarta;

Yusuf, M. \& Soraya. (2004). FaktorFaktor yang Mempengaruhi Praktik Perataan Laba pada Perusahaan Manufaktur yang Terdaftar di BEJ. Jurnal Akuntansi dan Keuangan. Vol. 8, No. 1.

Undang-Undang No. 10 Tahun 2009 Tentang Kepariwisataan 